\title{
On ammonia-amidide of hydrogen
}

\section{Prof. Daniell}

To cite this article: Prof. Daniell (1843) On ammonia-amidide of hydrogen, Philosophical Magazine Series 3, 22:147, 498-499, DOI: 10.1080/14786444308636431

To link to this article: http://dx.doi.org/10.1080/14786444308636431

册 Published online: 01 Jun 2009.

Submit your article to this journal 준

Џll Article views: 2

Q View related articles $₫$ 
water, it soon becomes of a deep red colour, and deposits plombic acid; acids, added to the plombates, occasion the precipitation of plombic acid.

All plombates are obtained by calcining in the air a mixture of metallic lead and protoxide of lead. Thus, then, minium or red lead is one of the series of plombates; it is a plombate of protoxide of lead. It is well known that when a metal forms both an oxide and an acid, they generally exist in combination; as examples of this may be cited the chromate of chromium, tungstate of tungstenum, stannate of tin, \&c. \&c. Minium is then also arranged in this series of compounds.-1bid.

ON AMMONIA-AMIDIDE OF HYDROGEN. BY PROF. DANIELL.

Professor Daniell observes, that " if we add to a cold solution of bichloride of mercury a very slight excess of ammonia, a copious white precipitate is formed, and the liquid is found to contain exactly half the chlorine of the bichloride combined with hydrogen and ammonia as muriate of ammonia. The white powder, which has long been known by the name of white precipitate of mercury, contains all the mercury and the remaining half of the chlorine. Dr. Kane believes that it is a compound of chloride and amidide of mercury, and that its formula, adopting 202, the ordinary number for mercury, is $\mathrm{Hg} \mathrm{Cl}+2 \mathrm{~N} \mathrm{H}_{2}$.

"An amidide of mercury has, however, never been obtained in a separate state.

"When potassium is heated in dry ammoniacal gas, hydrogen is set free, and a compound is formed, which is a fusible solid of an olive-green colour, which has been supposed to be an amidide of potassium, or $\mathrm{Ka}, \mathrm{NH}_{2}$, but it likewise contains undecomposed ammonia. It has, however, been observed, that if ammonia were simply reduced to the state of amidogen in this process, 4 volumes should be decomposed and evolve 2 volumes of hydrogen, but in the numerous experiments of Gay-Lussac and Thenard, never more than $3 \frac{\mathrm{I}}{2}$ volumes were required to furnish 2 volumes of hydrogen, so that the constitution of the green substance must be considered as very problematical.

"Such is the evidence upon which we are required to review all the compounds into which ammonia enters with reference to this new radical, which has never been isolated or transferred, and to consider ammonia itself as an amidide of hydrogen, or $\mathrm{N} \mathrm{H}_{2}+\mathrm{H}$.

"Ammonium, which we have considered as the radicle of the common salts of ammonia (an hypothesis which we have found to be so remarkably confirmed. by the results of electrolysis), is then a subamidide of hydrogen, or $\mathrm{N} \mathrm{H}_{2}+\mathrm{H}_{2}$; and sulphate of ammonia $\mathrm{N} \mathrm{H}_{2}+\mathrm{H}_{2}+\mathrm{O}+\mathrm{S} \mathrm{O}_{3}$, or a sulphate of the subamidide of hydrogen; and oxalate of ammonia, $\mathrm{N} \mathrm{H}_{2}+\mathrm{H}_{2}+\mathrm{O}+\mathrm{C}_{2} \mathrm{O}_{3}$, an oxalate of the oxide of subamidide of hydrogen, and so on with the salts of the other acids.

“ An immense amount of ingenuity has been expended upon this hypothesis, but, as the nature of chemical analysis has been most 
happily illustrated by the resolution of a word into its letters *, so we cannot help being reminded by this and similar transpositions of eiements, of that ingenious exercise of the mind which is afforded by the literary conceits called anagrams; in which the letters of a word are required to be transposed so as to form another word; unfortunately, however, the true chemical combination is not, in general, so obvious as the literal.

" The hypothesis of amidogen does not appear to clear up any of the difficulties which attach to some of the ammoniacal compounds. and is therefore objectionable, as unnecessarily introducing a confusion of ideas and nomenclature which is much to be deprecated in elementary teaching."-Daniell's Chem. Phil., edit. ii. p. 671.

\section{LARGE MASS OF NATIVE GOLD FOUND IN THE OURAL MOUN- \\ TAINS.}

Humboldt lately transmitted to the Academy of Sciences of Paris, a notice by M. de Koscharoff, an officer of the Russian Mines, regarding a mass of gold of large size, recently found in the Oural. The largest mass of native gold which had previously been found in the Oural Mountains, weighed upwards of 22 pounds avoirdupois; and it is that of which there is a plaster model in the Museum of Natural History at Paris. On the 7 th of November last, however, there was found in the same mountains a mass of native gold, weighing about 80 pounds avoirdupois.

The mines of Zarevo-Nicolaefsy and of Zarevo-Alexandrofsy, situated in the alluvial auriferous deposits of Miass, on the Asiatic side of the southern portion of the Oural, have already afforded more than 13,300 avoirdupois pounds of gold. It was in this alluvium that, in 1836, the large mass of 22 pounds, and several others of from 8 to 14 pounds, were found at the depth of a few inches under the surface.

Subsequently to the year 1837, the mines of Nicolaefsy and Alexandrofsy seeming exhausted, new explorations were made in the neighbourhood, and especially along the river Tashnow-Targanna. Great success attended the search for gold in the marshy plain, and the whole valley had been searched except that part of it occupied by the building in which the washing operations were carried on.

In 1842 it was resolved to remove the houses, whereupon sands were met with of immense richness, and lastly there was discovered, under the corner of a building, at a depth of three yards, a mass of gold weighing more than 79 pounds avoirdupois. This mass is placed in the collection of the Corps des Mines, at St. Petersburgh. According to the information given by M. de Humboldt in the third volume of his Examen Critique de la Géographie du nouveau Continent, the mass of gold found in the Oural, in 1826, was inferior in weight to that discovered in 1502 in the alluvium of the island of Haiti, and inferior also to that found in-1821 in the United States,

* "Whewell; Philosophy of the Inductive Sciences, vol.i. p. 362." $2 \mathrm{~L} 2$ 